○硲田猛真 ${ }^{1}$ 、間 三千夫 ${ }^{2}$ 、上里 迅 ${ }^{1}$ 、榎本友美子 ${ }^{1}$ 、中原 啓 ${ }^{1}$ 、榎本雅夫 ${ }^{12}$

1）りんくう総合医療センター 市立泉佐野病院 耳鼻咽喉科、2）信愛女子短期大学

\title{
【はじめに】
}

シーメンス社の一部の補聴器に搭載されている「サウンドスムージング（以下 SS)」は新 しいタイプの雑音抑制機構で、短時間の衝撃音を抑制する。特に、食器のぶつかる音や新聞 紙などのバリバリ音の抑制に効果的とされている。これの効果を検討することを試みた。

【対象と方法】

まず、雑音音源を作成した。SS の特徴は食器音や紙のバリバリ音の抑制であるが、この ような雑音源の標準的なものは見あたらなかったため、自作した。紙のバリバリ音を録音し、 コンピューターを用いて、ほぼ定常部分を抜き出し、音圧をノーマライズし、これを繰り返 させることで時間を伸張して、検査中持続できるようにし、CD-Rに記録した。記録された 波形の一部とスペクトル分析結果を図 1 に示す。

CD ラジカセで、この CD-R を再生し、騒音計（A 特性）で音圧レベルを校正した。 実験 1 : 波形の観察

再生した CD-R の音を SS 搭載の補聴器（motion500MVC+）に入れ、その出力をマイクで 拾い、どのような音になっているか、コンピューターで波形を観察した。また、語音明瞭度 検査音も同時に出して、その際の波形も観察した。

実験 2 : 聴力正常者での検討

聴力正常者 10 名に SS 搭載補聴器（motion500MVC+）をかけてもらい、CD-R の雑音下 に語音明瞭度を測定した。

補聴器は、250、500、1k、2k、4kHz の聴力レベルがそれぞれ 30、30、30、40、50dB の 難聴者用に設定されたものを用いた。利得は $1 \mathrm{kHz}$ で $10 \mathrm{~dB} 、 3 \mathrm{kHz}$ 付近が最大で、 $30 \mathrm{~dB}$ 程 度になっていた。リニアの設定とコンプレッションをかけた設定を用いたが、コンプレッシ ヨンは、 $1 \mathrm{kHz}$ では $40 \mathrm{~dB}$ 入力で約 $20 \mathrm{~dB}$ の利得、 $90 \mathrm{~dB}$ 入力ではほぼ $0 \mathrm{~dB}$ の増幅になってい た。

$\mathrm{CD}-\mathrm{R}$ の雑音は、騒音計 $\mathrm{A}$ 特性で $70 \mathrm{~dB}$ とし、検査音は $67 \mathrm{~S}$ 語表を用い、音圧は $60 \mathrm{~dB}(\mathrm{SN}$ $-10 \mathrm{~dB}) 、 50 \mathrm{~dB}(\mathrm{SN}-20 \mathrm{~dB})$ とし、リニアで SS オフ、リニアで SS オン、コンプレッション でSSオフ、コンプレッションで SS オンの計 8 条件を測定した。

\section{症例検討 :}

サウンドスムージング機構を搭載している補聴器を装用した 4 症例で語音明瞭度の低下が ないか調べた。

【結果】

実験 1 ：補聴器の特性をリニアにし、SS オン、SS オフ時の波形を図 2 、図 3 に示す。図 2 は CD-Rの雑音のみ、図 3 は CD-R の雑音下に語音明瞭度検査の説明文が流れている部分 である。いずれも瞬間的な音が削られていることが判る。スペクトル分析では大きな影響が 出ておらず、特定の周波数をカットしたのではないこともわかる。

実験 2 : SS オン時には、CD-R の不快な雑音は明らかにカットされていた。 
語音明暸度の平均は SS オン時には SS オフ時より悪化はみられなかった（図 4 ）。語音明 瞭度の差の分布を見てみると（表 1 )、低音圧(50dB) の刺激では SS オン時の方が明瞭度が 高い例が多かった。ただし、対象者によっては、SSがオンになると、むしろ聞き取りにく いとの意見もみられた。

症例検討：裸耳での最大語音明瞭度はそれぞれ 90、85、85、95\%、装用下では 90、85、90、 95\% で明暸度の低下はみられなかった。また、いずれの症例も雑音が気にならなくなって いる。

\section{【考察】}

SS は短時間の衝撃音を検出し、その衝撃音の利得を下げる機構である。AGC などでは、 全体の利得が下がってしまうため、会話音も減弱し、音声が聞き取りにくくなるが、SS で は会話音のパターンを検出し、そのような音は利得を下げないようにしているとのことで、 会話音は影響を受けず、音声などの利得を保持したまま衝撃音の利得を抑制できる。ただし、 SS をかけ過ぎた場合には明瞭度にも影響が出る場合がある、とのことである。今回の検討 では明らかな語音明瞭度の低下は見られず、むしろ低音圧刺激時には明瞭度が改善する可能 性が示唆された。

補聴器装用時には種々の雑音が気になることが多く、このために装用がうまくいかない症 例も多くみられる。新聞紙のバリバリ音や食器の音などは気になる音の代表格である。SS により、これらの雑音は軽減でき、結果的に補聴器の装用がうまくいくようであれば、有用 であると考えた。ただし、実験 1 で聞き取りにくさを訴えた例もあり、症例によっては注意 が必要と考えられた。

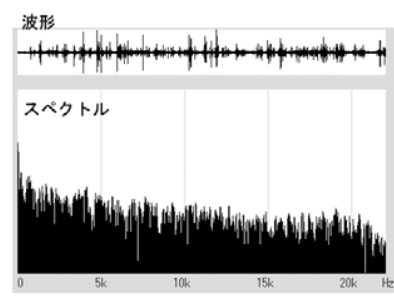

图 1 作成した雑音

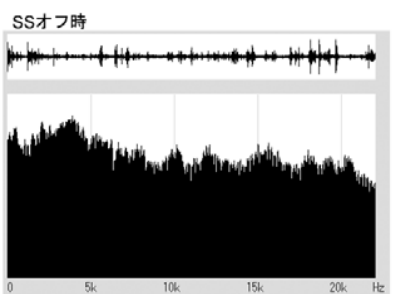

图 2 SSオフ時とオン時 (CD-Rの雓音)
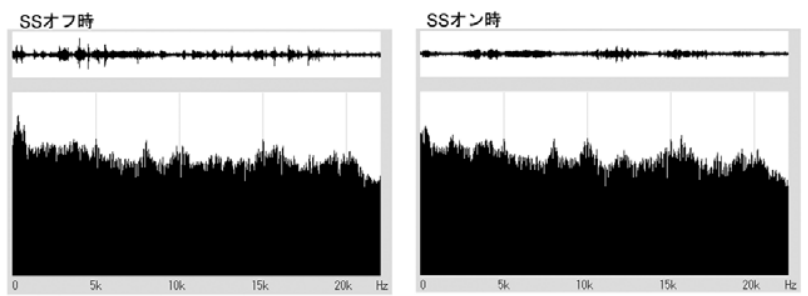

图3 SSオフ時とオン時（雓音十語音明䁖度説明文）

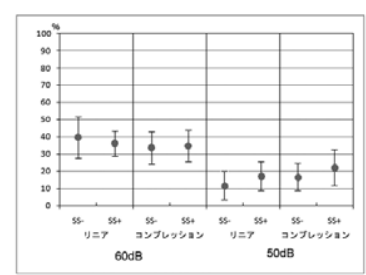

图4 実騃 2 の語音明瞕度
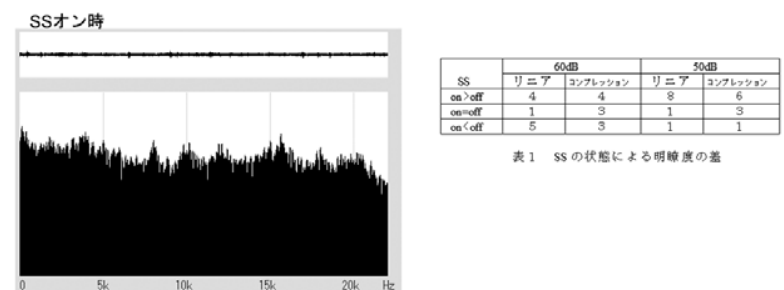

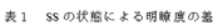

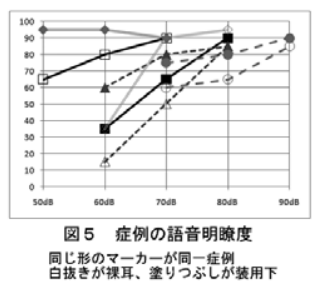

